Florida International University FIU Digital Commons

FIU Electronic Theses and Dissertations

University Graduate School

$11-12-2015$

\title{
Zora Neale Hurston and the Narrative Aesthetics of Dance Performance
}

Jennifer M. Sittig

Florida International University, sittigjm@gmail.com

DOI: 10.25148 /etd.FIDC000200

Follow this and additional works at: https://digitalcommons.fiu.edu/etd

Part of the Literature in English, North America Commons

\section{Recommended Citation}

Sittig, Jennifer M., "Zora Neale Hurston and the Narrative Aesthetics of Dance Performance" (2015). FIU Electronic Theses and Dissertations. 2303.

https://digitalcommons.fiu.edu/etd/2303

This work is brought to you for free and open access by the University Graduate School at FIU Digital Commons. It has been accepted for inclusion in FIU Electronic Theses and Dissertations by an authorized administrator of FIU Digital Commons. For more information, please contact dcc@fiu.edu. 


\title{
FLORIDA INTERNATIONAL UNIVERSITY
}

Miami, Florida

\section{ZORA NEALE HURSTON AND THE NARRATIVE AESTHETICS OF DANCE PERFORMANCE}

\author{
A thesis submitted in partial fulfillment of \\ the requirements for the degree of \\ MASTER OF ARTS \\ in \\ ENGLISH \\ by \\ Jennifer M. Sittig
}

2015 
To: Dean Michael Heithaus

College of Arts and Sciences

This thesis, written by Jennifer M. Sittig, and entitled Zora Neale Hurston and the Narrative Aesthetics of Dance Performance, having been approved in respect to style and intellectual content, is referred to you for judgment.

We have read this thesis and recommend that it be approved.

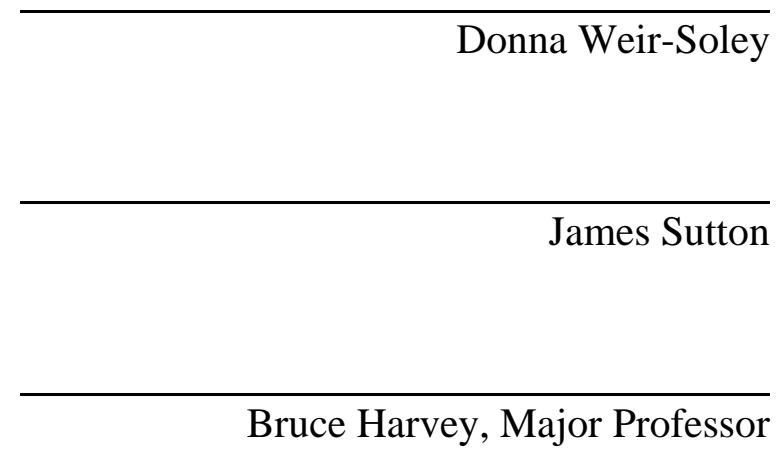

Date of Defense: November 12, 2015

The thesis of Jennifer M. Sittig is approved.

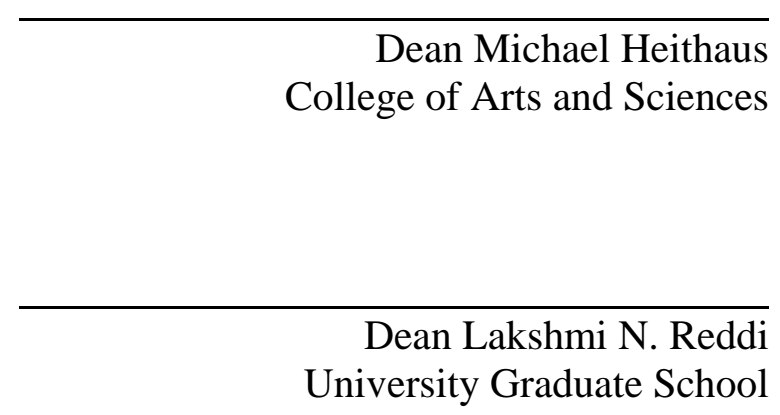

Florida International University, 2015 
ABSTRACT OF THE THESIS

ZORA NEALE HURSTON AND THE NARRATIVE AESTHETICS OF

DANCE PERFORMANCE

\author{
by \\ Jennifer M. Sittig \\ Florida International University, 2015 \\ Miami, Florida \\ Professor Bruce Harvey, Major Professor \\ Zora Neale Hurston's literature involves dance and performance. What makes
} this a viable topic of inquiry is her texts often exhibit the performative, whether portraying culture or using dance and associated folk rituals to create complex meaning. Hurston's use of black vernacular and storytelling evokes lyrical expression in Their Eyes Were Watching God. African and Caribbean Diasporas in Hurston's literature reflects primitive dance performances and folklore. This novel requires lyrical analysis. The storytelling feature of performance arts and reclamations of the body are present in Hurston's text. In recent academic settings, the body has come to occupy a crucial place in literary and cultural texts and criticism. Hurston’s versatile material and anthropology techniques are instrumental in reshaping dance history. A new archetype for theorizing the body has surfaced, where the body of text is performance and lyrical expression. 


\section{TABLE OF CONTENTS}

CHAPTER

PAGE

I. Dust Tracks on a Road: Authorial Self-Making and Performative Affirmation.................................................................

II. Hurston as Interpreter of Black Folklore and Dance Ritual: Choreography and Celebrations of the Black Diaspora.........................................17

III. Their Eyes Were Watching God: The Body-in-Motion-Narrative Motifs, Symbols, and Rhythmic Structures......................................26

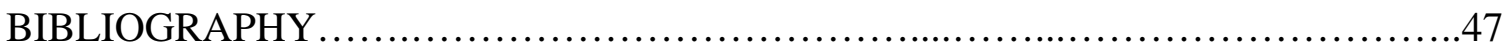


Zora Neale Hurston and the Narrative Aesthetics of Dance Performance

I. Dust Tracks on a Road: Authorial Self-Making and Performative Affirmation

During The Great Migration (1910 to 1970) of blacks from the South to the North, Hurston became known for having "the map of Dixie on her tongue." Hurston was born in Nostasulga, Macon County, Alabama on January 7, 1891. The South and, specifically, Eatonville, Florida, where she grew up, is a central setting in Hurston's literature and provides much of the background for her texts. Eatonville was the first allblack incorporated municipality in the United States. Zora Neale Hurston, for one, felt at home in Eatonville while spending time on Joe Clarke's porch. It is "true that Hurston's book contains what most of her contemporaries could not or would not chronicle: the cohesion, integrity, and stubborn exuberance of rural black culture” (Setterberg 631). Hurston took to wandering early, which worried her mother who felt a nemesis of hers had scattered "travel dust" at their door the day Zora was born.

Few white professionals of anthropology had investigated the South as Hurston did. This was a familiar place for her. The South was her home. Hurston's primary reason for collecting folklore, music, and dance was to dispel certain stereotypes of African-American lifestyles and heritage. She did succeed in this endeavor. Hurston was able to acquire and document African-rooted dance and folklore from North America and the Caribbean. This background material will provide clarification of Hurston's exposure to dance, which led to her academic and literary use of it.

Hurston attended Barnard College in New York City and developed a working relationship with Fannie Hurst, author and celebrity, which helped her gain social acceptance. Hurst is known for the novel Imitation of Life, which has been made into 
movies. Hurston was encouraged to attend the college's junior prom and bring "a man as light as" herself. Also, her classmates offered to "exchange dances with" her partner. Hurston found these requests humorous for their blatant racism toward her. Her classmates must have been making a conscious decision, according to Zora, since "Dancing is such an intimate thing." Hurston did not attend her junior prom on account of the preparation costs and the undeniable, but subtle, racism. She did not want this racial difference to hinder an evening and her date. Still, Hurston wanted acceptance on an equal, authentic level with her peers. She could be a recluse or, in her words, the "dark rock surged upon," yet she remained focused on her career. She "preferred a Harlem rent party to a formal dance at the Ritz any day of the week" (Boyd 108). So, the environment of the junior prom was not Hurston's idea of an enjoyable evening. According to Fred Setterberg of “The Georgia Review," Hurston is placed among Billie Holiday, Bessie Smith, Josephine Baker, and Katherine Dunham: "She followed her own road, believed in her own gods, pursued her own dreams, and refused to separate herself from 'common people"” (631). Hurston was among the best and brightest during the Harlem Renaissance.

\section{Dance: Hurston's Exposure to the Art Form}

Living with her brother Bob and his family in Memphis, TN for a brief time, Hurston experienced the dance environment of Nashville, where the dance called the Black Bottom originated. Boyd details the dance "The black bottom which required dancers to slap their backsides while hopping forward and backward, stamping their feet and gyrating their hips was born in the jook joints not far from where the Hurstons lived” (Boyd 66). Hurston recounts, "Jook [or juke] is the word for Negro pleasure house [...] 
where men and women dance, drink, and gamble.” Years later, she did document the Black Bottom dance form and its origins in Nashville. Later, Hurston would experience rent parties, where Black Bottom competitions took place. The "jook-joint[s]" were venues of the Black Bottom. "Harlem itself was full of smaller halls, nightclubs, afterhours joints, and impromptu rent parties where dancing was the main attraction” (Jonas 177). Big stars would perform at such places after their paid gigs. At these parties Hurston "rarely drank - despite Prohibition, rent parties were usually well lubricated but she loved to dance" (Boyd 95). Hurston, known as "the party," was the conversationalist and storyteller. She took center stage on numerous occasions. She also danced at these parties, "until her legs were wobbly."

Upon Hurston's return to Harlem after “The Crash” on Wall Street in October of 1929, she was urged to try the newest dance craze, the Lindy Hop. The Lindy Hop was named after Charles Lindbergh, who was the first pilot to fly solo across the Atlantic Ocean. 'The Core of the Lindy was the so-called 'breakaway.' After doing a syncopated but flowing two-step together, the couples parted and went into solo beat; the challenge was to do something new and difficult with an air of effortlessness, and then come back together seamlessly without missing a beat” (Jonas 179). The dance was as competitive as the Black Bottom. During this period, Hurston was called to do a presentation of dancing, skits, and songs collected from the South for her patron, Charlotte Osgood Mason. Boyd terms this a "show-and-tell” (193). “Hurston’s footage showed deeply black children in Florida playing games and dancing like no one was watching” and using the world as a natural untouched stage, making the collection prime material (193). The 
photo and film footage she collected reflected the authentic material she had researched, which shared an intimate nature with its subject.

Rhythm and movement are part and parcel of how Hurston recorded dance and showed it as a cultural manifestation. On Hurston's way to church, religion being an integral part of her life, the gospel rhythm and spiritual movements would overtake her. Hurston identifies dance in this setting, too, recounting the collective joy made unto the Lord by the congregation. The rhythmic song could lead to an impromptu dance. The “drum, a rattle, and their [the congregation's] own two feet," enacted a dance whether the congregation was conscious of its occurring or not.

Hurston attended bimonthly payday parties while collecting folklore in the South. The parties included drinks, music, and dance. The dance of choice was square dancing. Hurston, having learned square dancing from her long-deceased mother, wanted to join. She waited while other women got asked. Then a man informed her they thought she was wealthy and, therefore, of a higher class system and did not want to ask her out of courtesy. After dispelling their notions and placing herself in the context of their environment, Hurston’s dance card was filled. "Vocally urged by all to 'spread her jenk' to have a good time Zora did, and so did everyone else” (Boyd 164).

Hurston had no racial or sexual qualms and partied "at the Rockland Palace" alongside "homosexuals and heterosexuals" (Boyd 131). She was immersed among prominent figures from the period. Her values of reflection, preservation, and restoration of the African-American community did become key components of her work. The Harlem Renaissance area was the place to be and be seen. Hurston made artistic friends and acquaintances on the Harlem scene. 
Carl Van Vetchen, who frequented Harlem, a close friend to Hurston and a popular white writer and photographer, came under fire for his novel, Nigger Heaven, published in 1926. The more conservative leaders of the Harlem Renaissance movement, such W.E.B. Dubois, thought the novel was a disgrace to the progress of the race. Others, such as Hurston and Hughes, felt Van Vetchen's novel was "an accurate reflection of uptown life" (Boyd 127). The white audience commended the novel more or less because of the accuracy and truth behind the hot spot of Harlem. Van Vetchen, in an attempt to defy the bans imposed on him at nightclubs, enlisted the help of "a formidable escort: Zora Neale Hurston” (127). His evenings on the town became a topic of the "in crowd." Hurston accompanied Van Vetchen on many of his nights in the city and to costume balls. Those who ridiculed Van Vetchen would have preferred he wrote about prominent events. Van Vetchen presented open and direct information about the sexual happenings of Harlem. Hurston and Van Vetchen's dedication to a shared point of view and methodolgy, even when under fire by colleagues, is attributed to their bond and their relationship.

Charlotte Osgood Mason was a wealthy American socialite and philanthropist. She was in tune to the trends of the Harlem Renaissance. She was a patron of Hurston, Langston Hughes, and Alain Locke to name a few artists. Godmother is the nickname Mason coined for herself as she set out to support the New Negroes. She was interested in helping these individuals to capture the primitive. She brings in Alain Locke to help her secure what they termed as "black primitivism." Mason with Locke would push Hurston, for five years, and Hughes into situations and contracts that would later go sour as a result of Mason's controlling use of the primitive material. Through Carla Kaplan's 
Zora Neale Hurston: A Life in Letters you can see how Hurston walked a fine line of collecting folklore on Mason's ticket and her urge to make it on her own with the folklore on stage through performance and dance. Hurston chooses her words wisely and the connotation is thick. She often signed the closing with a clever note such as "your little pickaninny” or “your devoted pickaninny,” which is a little, dark-skinned person or racial depiction to create humor or a grotesque feeling (Kaplan 22).

While in Miami, Hurston witnessed the Bahamian music and "jumping dance," which intrigued her and drew her to the Bahamas. The rhythms of the "jumping dance" had more extensive African origins than anything Hurston had heard or seen. Without permission from Ms. Mason, Hurston collected "Bahamian Songs and learned how to 'jump: - that is, how to dance in the way of the folk; she also had recorded three reels of Bahamians performing their native folk dances, including an impressive 'Fire Dance'” (Boyd 187). She returned home with a "Bahamian conga drum, called a gimbay" made of lambskin. Hurston's trip left her in high spirits despite a close brush with death given she had survived a hurricane. This experience left her humble and introspective, calling into question what she valued and prioritized. Out of this endeavor, she produced in the Journal of American Folk-Lore, "Dance Songs and Tales from the Bahamas," which appeared in the 1930 summer issue. In this article, she discusses the movements in detail: "These songs accompany the exceedingly African folk dance called the fire dance. It was done in the nude formerly, but the British Government has put a penalty on that” (Hurston 294). Censorship is evident throughout performances of African-based songs and dance. The Bahamian material was not of as great importance to her patron, Ms. 
Mason, as the Southern American material had been, but she did grant Hurston permission to put the material in journal format.

\section{Theater: Hurston's Artistic use of Dance}

Hurston's choreographic interaction with the production was essential for a better understanding, during the period, of what she was attempting to portray to her audiences. Hurston took her collection of folk songs and dances and sent them to Hall Johnson, a famous black choral director of the time. Johnson in response told Hurston, "The world was not ready for Negro music unless it were highly arranged.” Johnson may have been truthful, but if "Negro music" was not "highly arranged” then was it not worthy of critical attention? Hurston saw Johnson's reply as a “determined effort to squeeze all of the rich black juice out of the songs, just like she had seen during her work and writing for Fast and Furious and present a sort of musical octoroon or farse to the public. Like some more 'passing for white’” (Boyd 227). Hurston was not partaking in the act of passing and produced the original West Indian fire dance she had recorded in the Bahamas. She wanted them to be presented "in the raw." The group was made up of sixteen Bahamian dancers to "celebrate (and contextualize) the mighty, unembellished voices of ordinary black folk.” While still upset by Johnson’s remarks regarding her collection, she still contacted him about combining "her dancers and his singers for a concert," with which he agreed. After weeks of no rehearsals, Hurston became frustrated with Johnson and, on one occasion, loudly escorted her dancers out of the studio when Johnson's singers made derogatory racial comments in the dancers’ presence. Quickly, she became self-sufficient and acquired her own talented group of singers. In similar circumstances, Hurston stood true to her beliefs, thus instilling racial pride in herself and others. 
Hurston, enraged by Johnson, set out to prove the quality of her collection, dancers, singers, and instrumentalists. As for the cast, Hurston's "color-conscious casting was intended to make a statement” (Boyd 228). Ms. Mason, the owner of Hurston's captured footage from the Bahamas by contract, released the material to Hurston by request and a date and place were made, "Sunday, January 10, 1932, at the John Golden Theatre” in midtown Manhattan.

Hurston, along with Alain Locke, sought to target an audience for The Great Day. Hall Johnson commended the performance as a brilliant success. Johnson was so blunt he said, "I really came to see you do a flop, but it was swell" (231). It was not a financial success, but rather provided acclaim for her work. "Though she was showered with letters and phone calls, she had 'no feeling of glory,”” she said, “'because I am too keenly conscious of how far short I fell off the mark at which I aimed.'” Hurston did not earn a profit and rather owed a debt to her performers. She was able to get a loan from Ms. Mason, which became a tab.

Hurston's theatrical contributions came during the Great Depression and the arts, in general, were not rewarded or frequented during this global, economic catastophy. Ms. Mason encouraged Hurston's collecting of folklore, but envisioned it in print. Hurston felt that, in keeping with the oral tradition of folklore, the stage was a more suitable outlet for the material collected. After From Sun to Sun, the play similar to her The Great Day, she was praised for her multifaceted talents. Hurston's dancers and cast were photographed for the April issue of Theatre Arts in 1932 and were invited by the Folk Dance Society "to perform at New York’s chic Vanderbilt Hotel” (Boyd 233). Rehearsals were taking place each day. "Zora was whirling through her days, she 
reported, 'rushing, writing notes, phoning and scratching my nappy head.'” (233). There was a discussion of taking the production to London for the summer. Hurston was happy with the progress of the production and how well it did with audiences. The different aspects of a theater production enthralled her, highlighting her innate ability to command the stage. Her material was original and factual. She would end each performance with the Fire Dance, hence it became her trademark. The Fire Dance was an acclaimed addition to her stage production: "It was good it was the last thing, for nothing could have followed it," said Hurston. Not able to turn a profit despite critical acclaim, she sought out more stable monetary endeavors.

After Hurston's praise for her stage work, Walter White of the NAACP requested Hurston to “supply dancers for a musical based on Rene Maran’s controversial Batouala, a 1922 novel portraying native life and various sexual initiation rites in an African village” (Boyd 239). The production was underway with a cast to include Paul Robeson. Hurston wanted to be a part of the actual musical and offered to perform, but Batouala lacked funding as a result of the Great Depression. Ms. Mason was not surprised and harshly commented, "The news here seems to be that they are still putting Negro plays on the stage and they are still falling off!”

Hurston continued to work on From Sun to Sun on the stage at Rollins College near Winter Park, FL, where she felt comfortable in the "slow-motion lives" (Boyd 239). She felt relaxed and whole in her childhood surroundings of Florida. The Fire Dance and the children's games Hurston recorded are evidence of the African-American and Caribbean heritage. Hurston documented the happenings of the town and learned the "the chicken dance" (Boyd 240). 
Hurston sought out dance, song, and black-lore for additional income. In 1934, Hurston and her cast reassembled to perform All the Live Long Day, earning prestige and success. It was stated by The Sandspur, to be "unselfconscious simplicity." Hurston ended with her trademark, the Fire Dance. The Sandspur went on to say, "But most unique were the dances... Colorful, primitive, intense dark girls and men danced to the beat of an African drum, a chant and the pounding of naked heels. Presented humbly [...] with all the spontaneous enthusiasm and brilliance of natural artists” (Boyd 250). This particular reviewer had wonderful feedback about the quality of the performance, but the term "primitive" suggests he was not fully aware of "African"-rooted performance as being culturally sophisticated. "Black vernacular dance idioms, helping to reorient those idioms away from the racist legacy of blackface minstrelsy and toward an understanding of how African-derived practices” are proof of the representative changes in interpretation (Kraut 434).

Hurston introduced the Fire Dance of the Bahamian community to Lomax and Barnicle, colleagues in the field (the Everglades), who were in awe of the closeness to African traditions: "Lomax and his assistant wore blackface to avoid harassment by whites; it was Hurston’s idea” (Setterburg 637). Later, while working with the Federal Writers' Project, Hurston performed the Fire Dance with a group of teenagers. She mentions the use of teenagers "were not as suggestive or shocking" since they had not attained their adult shape. The teenage bodies were less offensive than their adult counterparts.

Hurston's reputation is growing and she is receiving acclaim for her contributions to dance historiography. Hurston's versatility is instrumental in reshaping American 
black dance ritual and, more importantly, its vitality as a legitimate art and cultural form. Dance is significant in the creative literary discussion.

\section{Anthropology: Hurston's Feminist Approach}

Hurston's experiences with social dance were a means to be self-reflexive, at least in an anthropological sense. In Hurston's essay, How It Feels to Be Colored Me, she discusses her emotions during a performance at The New World Cabaret. Hurston commits to the music, attributing her participation to her heritage as an African: "I dance wildly inside myself: I yell within, I whoop: I shake my assegai above my head, I...mark yeehow! I am in the jungle and living in the jungle way. My face is painted red and yellow and my body is painted blue. My pulse is throbbing like a war drum" (Hurston 154). The music entices dance while consuming her body movement. European and American descendants are more reluctant to enjoy the dance, because of presumptions of acceptable social behavior.

Hurston sets out to (re)define the term "primitive" by moving in and out of dominant culture. Using this to her advantage, she was able to move from the margins to the core of her subject and anthropology work. Out of what may have seemed, to Hurston, a vicious cycle, she is a pioneer in changing the mindset of those who considered folk and ritual "primitive." It is all too often people fear what they do not understand, thus regarding what they fear as less than themselves, thereby "He enslaves it” for personal benefit (Fanon 128). “The sharing of joy -- whether physical, emotional, psychic, or intellectual -- for a bridge between the sharers, which can be the basis for understanding much of what is not shared between them, and lessens the threat of their 
difference" (Sister Outsider 56). The lack of connection and participation on either racial end (race being a construct) contributes to the overall lack of cooperation.

Hurston, as do her characters, crosses borders. She crosses borders to collect folklore. African-American women in particular "Transgress social, cultural, and epistemological borders” in history and culture, such as Hurston did (Billingslea-Brown 2). By way of using the "mask," black women have an inside-out paradigm, they overlap realities and shift identities. Bell Hooks, the author of "Zora Neale Hurston: A Subversive Reading,” relates Janie's journey in Their Eyes Were Watching God geographically and physiologically to Hurston's life journey. She felt the migration did have its positives, but "was also violent and costly. She saw the results of the Great Migration as terrifying and spasmodic, unbearable inhumane and devastating to those left behind. [...], rural black people were being forgotten, disappearing” (Krasner 534). Hurston celebrated the process of self and insisted "on the importance of female selfactualization” (Hooks 245). She would never see the full result of her insistence in her time.

Hurston studied under the "father" of anthropology, Franz Boas. Using his methods, Hurston's ethnographic, anthropologic, literary, and historical accounts of her findings were rooted in black feminist anthropology. Recently, Hurston is cited for contributions to folklore from Florida, New Orleans, Jamaica, the Bahamas, Haiti, and Harlem: "She trained her ear to listen well and took seriously the value of the insider's (emic) perspective well before it was popular in anthropology” (Bolles 39).

In Hurston's anthropological work, Tell My Horse, she documents the initiation ritual of womanhood and marriage. Women in the Caribbean are not given the same 
respect as their male counterparts, but rather are owned and need placement. Hurston felt it was a contradiction for the men, who come from a past of enslavement, to then enslave their wife, children, and animals. Hurston reports: “It was a great tragedy to look at American women whom he thought the most beautiful and vivacious women on Earth, and then to think what little use they were as women” (Hurston 288). According to this young man from St. Mary's who visited with her at the summer house, women with brains were "wasted material” in the area of love. In the Caribbean, women are trained to be quality lovers and companions. The woman's role of "love and softness and peace" is adhered to with a general respect. The naming of things in a feminine manner is "for some mule or horse or obeah [magic or witchcraft] women” (321). There is a sense of honor, justice, and submission in these names. Without the mule, horse, or woman, production and reproduction would be hard and cease. Hurston broke ground for women of this area. A lavish feast took place for Hurston, which had never happened to another woman prior to her. The ritual "held on the ninth night after death," welcomed the spirit "the duppy" "and sang to it, danced for it, then bade it farewell forever" (Boyd 289). Hurston recounted the dancing as "so rapturous [...] that it felt as if the drums had become the people and the people had become the drums” moving in synchronization (289-290).

Hurston found her work as an anthropologist burdensome to her social career, but also wanted to befriend the people she would meet while collecting folklore, songs, and dances. "Her charge, as a social scientist, was to study them, not to get to know them and certainly not to entertain them” (Boyd 148). Hurston did entertain them, though, on her "Proscenium box" (Hurston 152) during childhood in Eatonville, FL. Hurston, more 
often than not, was the life of a party, telling stories and singing songs. Encouraging attention, she was now the outsider again, but in another form not racial, but occupational. She would "watch other people dance" and record their rhythms and movements, paying particular attention to detail (Boyd 148). The act of the dance, in general, rekindled Hurston's lifestyle and rent parties she had attended in the North. The role change for her was not smooth in all aspects; Hurston at times states she missed the fast-paced lifestyle of the North in comparison to the laid back lifestyle of the South. She was loyal to her fieldwork.

One of Hurston's “thrilling” findings included “a marvelous dance ritual from the ceremony of death” (Boyd 179). Hurston learned the death dance, rarely to be seen by outsiders, while in apprenticeship to Kitty Brown. Hurston noticed the religious influences of the region were Catholicism and hoodoo. People would pay Kitty Brown and others for her ability to perform such hoodoo on people who lusted for others outside the marital unit. Much of the money paid "Was used to compensate the assembled dancers and to set the table with cake, wine, and roast duck, and barbecued goat, which would feed the dancers as well as the spirit of Death” (Boyd 180). The dance ensemble was made up of "male and female, young and old" persons submitting to a ritual hierarchy. Hurston was given permission to dance for "Mother Kitty." Boyd details Hurston’s dance encounter -

Each of the six dancers had forty minutes alone on the floor, and the furious rhythm (created not by drum, which might have drawn police, but by heel-patting and hand clapping) sustained Zora and the others for the full three-hour ceremony. Though all of the dancing served the same purpose - to beseech Death 
to cut down the womanizer - 'there was no regular formula' to it, Hurston noted. 'Some of the postures were obscene in the extreme. Some were grotesque, limping steps of old men and women. Some were mere agile leapings. But the faces! That is where the dedication lay.' A person who had been danced upon was supposed to drop dead within nine days of the ritual. (180)

Once the ritual did what it set out to do, the spell was released as per the patron's request. Hurston met with many doctors of conjure, at least as many as she could afford. "Hurston felt this approach would yield the most thorough results since many of the less famous doctors knew some details not known to the bigger ones” (180). Hurston was acting as a "vacuum" collecting any information afforded to her. She has no moral reluctance about participating in such rituals, which reveals to us more about Hurston's adventurous side.

Hurston understood, and as the bass player was showing once again, our nation's truest anthem contains the funeral dirge of the New Orleans street band combined with the whorehouse piano and the last slave's work song and the bickering melodies of two hundred disparate points of origin, from Marseilles to Dakar, from Manaus to Guangzhoi, now stretched out over the American Plains like the hide of some mythical beast: the confluence of influences that nobody will ever be able to pick apart note-for-note. (Setterberg 643)

This metaphor speaks to the mixing of the races. Hurston did not suffer a color crisis. She does mention that people tried to be racist toward her, even her colleagues, but she had a strong will, earned from her young home life, and love for her work. 
What is Hurston's relationship to African Diaspora folk dance and her participation in American dance? She had a unique vision of black creative expression. Her goals were to take a dance style and move people's perception of it from savage or primitive and provide them with a vision of art and beauty and celebrate it. Hurston's artistic and creative vision for dance did fuel consumer interest in the Bahamian Dances. Her futuristic vision and the meaning of the dance she presented still were altered in their meaning and intent by the viewer beyond what and how Hurston presented it. What are the factors contributing to her slight recognition in the dance field? Her relationships, or lack thereof, with those on the Harlem Renaissance scenes did allow her outlets for her pursuit of performance arts.

The New Negro Movement mistook Hurston's performances as demonstrating a lack of intellect and commitment to progress for racially marginalized blacks in America. The dances of the era, such as the Lindy Hop, Ragtime, Tap and many others, stem from African roots. The dances, as they take place in their origins, the jook joints and the segregated Harlem scene, were seen by their white counterparts as disreputable. The Diaspora dance theme was at odds with the New Negro movement and Hurston was in the middle of these events. She believed the dances were better for stage than in print. Hurston showed the authenticity of her work, which was part and parcel of the African Diaspora. 
II. Hurston as Interpreter of Black Folklore and Dance Ritual: Choreography and Celebrations of the Black Diaspora

Zora Neale Hurston's literature involves dance and performance. Hurston's use of black vernacular and storytelling evokes lyrical expression in Their Eyes Were Watching God. African and Caribbean Diasporas in Hurston's literature reflect primitive dance performances and folklore. As a body of the text, Hurston's work requires lyrical analysis.

Zora Neale Hurston and her involvement with performative dance as it pertains to literature and anthropology have begun receiving consideration among scholars. She was a prominent writer, playwright, and director from 1925 to 1945 . Hurston incorporates African dance and its history in her writings using an ethnographic emersion technique to acquire accurate data and, in certain works, to provide an idiosyncratic portrayal of the art form. Lorenzo Dow Turner and Alain Locke mentored Hurston in her writing and development as an author. Amidst prominent figures, such as Katherine Dunham and Langston Hughes to name a few, Hurston would enjoy the pleasures of dance and use acquired anthropological methods to record her dance encounters. She would study anthropology at Barnard College, earning a B.A. in 1928, and would enroll in a graduate program at Columbia. She collected folklore in the South from 1927 to 1931, in the Caribbean (Jamaica, Haiti, and Bermuda) from 1937 to 1938 and, specifically, in Florida from 1938 to 1939. In Honduras in 1946, she went to gather more folklore. During the time she was writing, naturalism was the predominant literary style, which describes bodies and body movement. The Harlem Renaissance had its themes, too. "Including Richard Wright and Alain Locke, who were invested in the style of social realism and 
naturalism popular in the thirties. Writers hoped to depict 'real' African-American life, debunking racist stereotypes by embracing community values, political ideology, and positive self-image” (Bloom 51).

Hurston was a pioneer on the ethnographic and anthropologic scene. In her autobiography, Dust Tracks on a Road, Hurston’s imagination begins as a bit of freedom extended to her by her mother. Her mother encourages Hurston to "jump at de sun" (Hurston 13), which points to the expanse of hope and opportunity her mother affords her. Her father's wish was for her to understand and publicly abide by the laws of Jim Crow. He felt, "it did not do for Negroes to have too much spirit. He was always threatening to break mine or kill me in the attempt” (13). She sought independence in her art forms as she came of age. To some extent, "Everybody’s upbringing is a strange country, worthy of the best anthropologists” (Setterberg 635). She committed to the survival of her cultural heritage and did so with authenticity and authorship.

The prejudices she faced are visible in biographies and come directly from Mason or Locke, her mentors, and those who reviewed her work. Once, Hurston's play was listed under Hurston's name and in another instance, under a white director/producer’s name. The play listed under her white counterpart was more financially successful. Whites often took credit for black choreography.

Black popular culture during the 20s, 30s, and 40s was made up of black aesthetics. Then, why is it worth knowing about Hurston's contributions to dance and anthropology folk work if they are absent from archives? Also, what then is the definition of "folk" and "vernacular"? "Vernacular" would be the site and source of linguistic differences. Folk and African-American dance are one and the same. "Folk" 
would best be described as "other," a word first used when Europeans went in search of the exotic. Artistry during the Harlem Renaissance exemplified its relation to folk or the primitive. Hurston was sure to establish authority for her performances and set them apart from the mainstream. This artistic performance, "is further defined by its status as the single occurrence of a repeatable and pre-existent text or score” (Sayre 91).

Hurston's theatrical works were seen as authentic, because she was a black woman in a white man's theater space. Her play The Great Day was promoted as natural and genuine, "The real thing," and in the raw. The times are reflected in her play politically, economically, and ideologically. Hurston's plays were a form of commerce, even if they were seen at for-profit (Broadway) and non-profit venues. The artist's property was often the purchased right of a patron. For Hurston, this was no different. The New Negro Movement denounced blackface and minstrels. The juxtaposition of the "real Negro art theatre" versus the concert spirituals and black musical theater were presented as variances on the art scene.

There was a sense that the genuine Negro spirituals were in competition with the concert artists and glee clubs. These concert artists and glee clubs were authentic in their form, but not genuine. Folk, according to Hurston, did not need to be elite or high art as suggested by her colleague Langston Hughes. The argument was that black dancers were carefree and impulsive. A black musical pertained to the talent, not the content or context.

The Great Day was free from the traditional production commodities of the time. It was untouched materials from her anthropology trips. It was fresh and displayed the true Negro versus an artificially polished one. Alain Locke was the intellectual father of 
the New Negro Movement. His prominence lent credibility to Hurston’s premier theater performance in certain circles. Hurston's academic credentials and ethnographic research also propelled the authenticity of the performance.

Her display shows her as an involved anthropologist and not a marginal observer. She did brief her audience with a description of what they saw and would see. The pedagogical technique was instrumental in how the viewer perceived the performance. Storytelling was an intrinsic part of her folk concerts. She felt oral traditions of the South and Caribbean were better for the stage. Critics described the production as effortless and unpremeditated, natural.

Hurston on occasion did hire help for the other aspects of her play such as music and chorus, but she was dance director and did create new choreography. The Fire Dance was from the Caribbean Diaspora and brought to the American theater. Hurston was an artist and creator, dancer and performer. Her material is raw until borrowed and reshaped by her white counterparts. The title of choreographer for Hurston is debated, because her dances were thought to be unrehearsed and therefore not choreographed. Affirming too much labor would then take away from the folk. The term is used to give validity to this title for Hurston and her performers are meta techniques, where organic thought produces movement. When Hurston first presented The Great Day it was in its original form and had not been tampered with. Hurston had a serious interest in authorship, because copyright and competition was sure to ensue.

Alain Locke was a mentor for Hurston. Their split was in reaction to the artistic expression of black life and how it should be conveyed to the general public. The work is taken seriously, but still today, "Critique appears to be so threatening to many black 
folks, why there is the desire to silence and censor radical dissenting voices” (Hooks 54). When Their Eyes Were Watching God was published in 1937, Locke wrote a negative review, sealing their collegial split. He did not feel the novel promoted progress for the race. There was no consideration on the parts of Locke or Richard Wright when they wrote these reviews to consider the progress of the black female. Locke's review appears in Opportunity, "Having gotten rid of condescension, let us now get over oversimplication!” Wright states in The New Masses, "Miss Hurston seems to have no desire whatever to move in the direction of serious fiction.” Their Eyes Were Watching God revolutionized the depiction of black female sexuality in African-American literature. Critics of Hurston's work generally agree that in 1937, when she wrote her second novel, "The damaging effects of nineteenth-century sexual ideology on black women's subjectivities and writings were fully entrenched” (Weir-Soley 39). Racial expression and Hurston's input on the gender divide was now a hushed, but budding topic, to the dislike of the respectable black community of the Harlem Renaissance.

Hurston's creative work on Mule Bone: A Comedy of Negro Life with Langston Hughes became controversial in comparison to Locke and Mason. Locke also found a prodigy in young, intelligent, and handsome Langston Hughes. The issue of the main female character, a temptress in this piece, had not developed the way Hurston envisioned it. Mule Bone was Zora's story, but she brought in Hughes to collaborate. He then began to include Louise Thompson, their stenographer, as an additional collaborator. Hurston did not agree with this move and rewrote the story "carefully," not using what Hughes had contributed. He would find the play was being prepared for production at a theater in Cleveland while visiting his mother and the sole author on the play was 
Hurston. Hurston did not send a finished play out for production and had no knowledge how it had gotten to Cleveland. Clark, the reader at The Theatre Guild, had thought it was ready and forwarded it on, which solved the oddity of how it was released, a misunderstanding and not a vindictive move on Hurston's part. However, the relationship between Hughes and Hurston had been spoiled. Many of Hurston's contemporaries who have seen the manuscript for Mule Bone will contend the idioms within it are similar to her style. Later, Hurston, Langston, and Wright each wrote an autobiography, today noted as memoirs and myths turned to truth. Langston would review Hurston's autobiography in a condescending manner, still with resentment for their failed collaboration. Hughes stated in his review: "Girls are funny creatures!” She would later write an unbiased and positive review of his autobiography. Langston Hughes, Toomer, and McKay created women characters as primitive, as “other.” Here too, like Locke, Hughes and Hurston have a double binding of racism and sexism.

Hurston had other forms of competition in the arts and collection of folklore, specifically dance. Katherine Dunham viewed Hurston's folk dances, which then encouraged her to seek out the same research. Dunham wanted to become a famous dancer. Both Hurston and Dunham sought the Rosenwald Fellowship to collect and stage dances from the Caribbean. Hurston earned the fellowship; then it was rescinded. Dunham then got the fellowship. Colonel Rowe's perspective on the two ladies' research was they both sought out different aspects of the folk. Hurston did a Guggenheim Fellowship, which allowed her to make the trip as well. Hurston does comment about Dunham's trip to the Caribbean as being only thirty days long, which would not be enough to get ample and accurate work. Both Hurston and Dunham were observers and 
participants. Anthropologist Melville Herskovits describes it as two women with two different aims.

Hurston would go on to collect dance material she would later use as her trademark closer for the stage. The Fire Dance was made up of three different dances, the Jumping Dance, Ring Play, and Crow Dance. There was conflict about where and when these dances would take place. The dances displayed the colonial British censorship felt in the Caribbean. The Crow Dance was a dance of mimicry and nature, paralleling Hurston's early days of performing on the proscenium stage in Eatonville as travelers passed through to Orlando. The dances are universal to the origins of contemporary North American dances, but not all of the dancers in Hurston's performances were from the Bahamas. These Bahamian dances were the roots of dances such as the Black Bottom and the Slow Drag. Hurston arranged her dancers in a semicircle instead of a circle, which is how she first witnessed them. She did The Great Day,

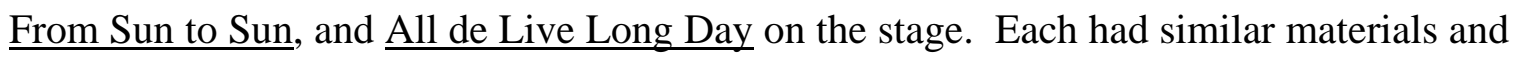
was a restaging of the former.

Authorship and authenticity continue to resurface as important factors in Hurston's career. She did have to ask for permission from Godmother Mason, her patron, to use or review the folk materials collected. The time, space, and spectacle determine what was appropriate for Western theater audiences.

Anyone who reads Hurston must know how to read her material with a perspective of how Locke and Mason’s relationship contributed or altered her authorship. There is a gap in the archives, but what does this mean? Keep in mind that Mason disliked the theater. Mason was an anthropologist as well. She always wanted tight 
control over the "primitive" collections of Hurston, which she confined in book covers. Hurston still found wiggle room in performance and power. Locke and Mason provided solicited assistance and unsolicited meddling. They are theatrical spies. On the day The Great Day premiered Mason, at the last minute, wanted the conjure material collected in New Orleans in Hurston's performance removed permanently. She claimed if Hurston were to perform the conjure material she would be defying the primitive law. For Mason, there was a distinction between the page and stage.

Hurston is the subversive trickster in her last relations with Mason. The Great Day is an original musical concert, spiritual, and black folk drama. The location was a historical and cultural marker for working black persons in the 1920s South. This play served as training for performance. The set-up of the storyline was a symbol of Diaspora migrating from Africa to the Caribbean and then North America. The Great Day is a reverse telling of the middle passage. It related to folk from Afro-Caribbean, urban, popular and rural heritages.

Hall Johnson’s performance, Run, Little Chillun!, was similar to The Great Day. A derogatory labeling of the Bahamian performers in his production degraded the dances and material. Some even called the West Indian’s “monkey chasers.” Johnson’s $\underline{\mathrm{New}}$ Day Pilgrims performers and a fictitious group did a moon worshiping skit that further made the folk look primitive. Hall used "voodoo" to portray all black people's religious practices.

The Hoodoo in New Orleans was a place of women's empowerment and proved to be able to solve social conflicts. The theater allowed for significance, where in print Hoodoo would not be as obvious. Hurston was initiated into both Hoodoo in New 
Orleans and Voodoo in Haiti. This shows her desire to connect fully with her African heritage and helps to explain why she hated to over-choreograph her dances. She liked the true "African" elements in the dances. Some of Hurston's dancers came to find African dance and theater work, which was trendy during the 30s. The Bahamian dances were fruitful endeavors for white choreographers, too. There was a cultural borrowing, exchange, and theft of the artistry collected and performed by Hurston.

The storytelling feature of performance arts is attributed to reclamations of the body and text in Hurston's work. In recent academic settings, the body has come to occupy a crucial place in literary and cultural texts and criticism. Hurston's versatile material and anthropology techniques are instrumental in reshaping the definition of the black dance tradition. A new archetype for theorizing the body has surfaced, where the body of text is a performance and lyrical narrative expression. Hurston redeems the black dance and maintains the aesthetics of the body, not just voyeuristic raw "primitivism." The "lyricism" of her texts implores us to capture the body-made-art notion. Hurston understands the sensuousness of the body, but also wants the viewer to see it as art. Her naturalistic approach to porch-side banter and storytelling reveals the colloquial "rawness," as it is lyrical and cultural. She is pragmatic to the "body" and delivers sophisticated aestheticism at the same time. Using a multimedia approach to her work, she avoids becoming a victim of the demands of any one format. 
III. Their Eyes Were Watching God: The Body-in-Motion--Narrative Motifs, Symbols, and Rhythmic Structures

Their Eyes Were Watching God and Every Tongue Got to Confess: Negro FolkTales from the Gulf States by Zora Neale Hurston include narration and dialogue that add musicality and complexity to the language. Vernacular language can be attributed to the everyday speech of her Florida upbringing, her Barnard education, her travels abroad for research, and her Harlem Renaissance experience, which put her in contact with the brightest and best, including her former teacher Locke, friend Hughes and others. The connection in lyricism and movement from Janie being objectified to being the subject are analyzed in this final section of my thesis.

\section{Lyricism (musicality) in Everyday Speech and in Narration in Hurston’s Work}

The lyrical language in Hurston's Their Eyes Were Watching God provides imagery, connotation, and figurative language. Their Eyes Were Watching God is also rhythm in sound, syllables, and voice. The everyday speech is important. Hurston refused to "clean up or compromise the realism of the Southern rural world she wrote about, where her love of the natural and the unvarnished comes through in descriptions of characters as well as the environment” (Guerin 258). The narration and lyrical banter dialogue comes from the folks Hurston grew up with and the folks she studied as an anthropologist.

This performance writing or poetic prose is filled with examples of density and verbosity. Examples of the verbosity are provided right from beginning; we have to "gets" a look at the "harmony in a song” - “What... Where's... Where... What...Where...Where... What... Why...?’” (2). This repetitive sing-song nature of the 
dialogue takes on a rhythm. Could it be the interrogative verbs blend with these static characters' inquisitive word play, adding to the lyrical characteristics? This is how Janie, as she returns to her home, sums up her trip, “'Ah been a delegate to de big 'ssociation of life. Yessuh! De Grand Lodge, de big convention of livin' is just where Ah been dis year and a half y'all ain’t seen me.” (6). The "Ah” is I, Janie, herself explained. She is aware of her age and mentions this, “Time makes everything old so the kissing, young darkness became a monstropolous old thing while Janie talked" (7). The "monstropolous" is a forgetfulness that is comparable to the size of a monster or her needs versus wants in love.

Hurston uses dialect authentically, but makes it especially lyrical. Hurston in many chapters uses italics for certain words to pinpoint humor or irony. Hurston aims to share her knowledge of this region using the dialect as a lyrical device, “"They wants to be there and hear it all”' (6) and “'Gal, it’s too good!”' (5). Right in the beginning of chapter 2, there are more than fourteen "Ah" or I's to help us understand the need for Janie to be self-aware.

Jody Starks, one of Janie's husbands, buys up lots of land in the community of Eatonville. Jody is the laughingstock of town, since no one has done something as grandiose as he with such purchases. Hicks and Coker, original homesteaders of Eatonville, are the first to meet Janie and Joe Starks (Jody) upon entering the town. These two provide comic relief throughout the introduction to this city. Their banter is, in effect, a dance dialogue. The six "Umph's” are used to provide affirmation, or a "yes” (36 \& 38).

\section{“Umph!”}


“You don’t believe me, do yuh? You don’t know de women Ah kin git to mah command.”

“Umph!”

“You ain’t never seen me when Ah’m out pleasurin’ and givin’ pleasure.” “Umph!”

'It's uh good thing he married her befo' she seen me. Ah kin be some trouble when Ah take uh notion.”

“Umph!” (36).

It acts as a refrain or choral response in a song. It makes the town sound as one, in unison. The community's "incredulous laughter burst out of their eyes." Again, judgment, talk with their eyes, lack of experience and a belief system blinds them. Jody suggests the need for a mayor and soon becomes the mayor. Their reason for not having a mayoral, authority figure, “Everybody’s grown”” (35). Jody buys the land from Captain Eaton and the town gets a new perspective on race, “'Us talks about de white man keepin’ us down! Shucks! He don’t have tuh. Us keeps our own selves down’” (39). This is Hurston's political point throughout her writings. She believes each individual can be accomplished and have the same opportunities with some diligence and determination, "I have seen that the world is to the strong regardless of a little pigmentation more or less” (Hurston 153).

Janie struck up a conversation with men on the store porch about Matt Bonner's mule, a yellow mule. The mule is a comparison to the strained relationship of Janie and Jody. Early in the novel, Nanny states that women are the mules in this world. Janie is introspectively questioning whether she is scared and stubborn like the mule, "Janie 
identifies with the mule, which remains stubbornly independent despite its master's efforts to beat it down. Ironically, while Jody's position in the city gives him the power to free the mule, his pride and ambition cause him to virtually enslave his wife. He can free Janie only by his death” (“Symbols and Metaphors” Web). Joe, alone, would participate in these conversations, but not start them. It was no problem for Janie to hear them, the "talkers," but if it concerned the big picture Janie was shoved away by Jody. The mule’s hard life is detailed by the people on the porch, “'Done been worked tuh death; done had his disposition ruint wid mistreatment, and now they got tuh finish devilin' 'im tuh death. Wisht Ah had may way wid 'em ali'”' (56). Seeing Janie's reaction, Jody tells the crowd, ““... I god, dat's enough!’” He buys the mule, like he did the town, but the owner tries to barter. Jody says, "Fifteen dollars? I god you'se as crazy as uh betsy bug! Five dollars’” (57). With the declaration of "I god" Jody places himself in a position with celestial power. He uses this phrase repeatedly. “'Didn’t buy 'im fuh no work. I god, Ah bought dat varmint tuh let 'im rest"” (58). This is a "new idea" to the people on the porch and "respectful silence" follows. Jody is seen as noble for acting on Janie’s notion. In time, the mule died. The ceremony was something in which the whole town participated. “'What killed this man?’ The chorus answered, 'Bare, bare fat.' 'What killed this man?' 'Bare, bare fat killed this man?' 'Bare, bare fat.' 'Who'll stand his funeral?' 'We!!!!!' 'Well, all right now'” (62). The lyrics are an introduction of Hurston's research on orality and folk into this novel, Their Eyes Were Watching God.

"Our beloved Mayor" is seen as a humorous statement by Janie and compared to the statement "God is everywhere.” (48). The townspeople start noticing Jody's treatment of Janie, because he begins treating them the same way. "'You kin feel a switch in his 
hand when he's talkin' to yuh,'” (49). They are the grass and he is the wind. They bend when he blows. He was a "king" in many eyes (73). This banter in the dialogue contributes to the lyricism and movement of the plot forward. "When Janie herself begins to speak to the reader directly, Hurston switches her style abruptly, capturing the sounds of Janie’s speech phonetically (in other words, writing as it might sound to hear her). Instead of 'I,' we get 'Ah.' Instead of ‘you,' we get ‘yuh.’” (Smoop).

Hurston's dialogue for each of Janie's male companions shows maturity and development of respect for herself. When Jody is on his deathbed, "Death" is a repetitive word used on page 84 to emphasize its coming for Jody and Janie’s urgency to say her peace to him. Immediately, with Tea Cake, Janie can banter and stretch her imagination. While with Tea Cake, Janie exclaims she is "hungry," yes, for food, but also for something more tangible, a physical relationship with Tea Cake.

Hurston has two dominant voices in this novel. "One of these voices-the narrator's-is lyrical, philosophical, and, for lack of a better word, refined in nature. The other voice-which we might say is shared by the characters in the novel-is down-to-Earth, colloquial, and real” (Shmoop). Drawn to the Bahamian dancers' Fire Dance, Janie likes to watch. The others, "saws" laughed and marginalized the group as being different and not of themselves. "Hurston wanted to stress how that culture survived the stress put upon it and became a redemptive source of beauty and value” (Ward 38).

Tea Cake is compared to Big John de Conquer, an African folk character, who is bigger than life. He is a trickster like the folk character and travels with the likes of Brer Rabbit. When Lias leaves the Everglades muck prior to the hurricane he states to Tea 
Cake, “If Ah never see you no mo' on Earth, Ah’ll meet you in Africa” (156). This brings this epic character to its origin. As the day progresses, almost ceremonially, Most of the great flame-throwers were there and, naturally, handling Big John de Conquer and his works. How he had done everything big on Earth, then went up tuh heben without dying atall. Went up there picking a guitar and got all de angels doing the ring-shout round and round de throne. ... [then he] went down to hell, beat the old devil and passed out ice water to everybody down there. ... God would rather hear a guitar. That brought them back to Tea Cake. (157)

This comparison also foreshadows Tea Cake’s death. Early in the novel, pgs. 66-67, the townspeople argue about Big John. They discuss how he "eat up Pharaoh’s tombstones" and never gets a whipping. Hurston in this context states that, “'Nature and salt. Dat's what makes up strong man lak Big John de Conquer. He was uh man wid salt in him. He could give uh flavor to anything." ' This is the image of Tea Cake for her. Upon the coming of the storm, "Motor looked up in his angel-looking way and said, 'Big Massa draw him chair upstairs.” Janie then says, “'Ole Massa is doin’ His work now. Us oughta keep quiet." They watch the door and "Six eyes were questioning God." The words His and God are italicized for emphasis. Hurston also uses this technique in moments of humor to give importance to a particular word and its implicit meaning. "He could give uh a flavor to anything." Hurston's own version of this writing is titled High John de Conquer. He is her "Clearest figure for residual African culture in America's South. She offers the conflated trickster/hoodoo root” for the humor and lyrical language (Cartwright 58). 
Hurston had collected oral tradition in the Southern and Gulf States, some of which are about “John and Massa Tales” or Big/High John de Conquer. Every Tongue Got to Confess: Negro Folk-Tales from the Gulf States, "Big Sixteen,” otherwise known as Big John de Conquer, is told by Jerry Bennet, who was about 39, born in Louisiana, when the story was recorded by Hurston. When Hurston recorded this storytelling, Jerry was a sawmill hand. His story of Big John takes him on a trip to catch (beat) the devil in a bet against his Marster. He digs with a shovel and hammer 'til he arrives at the devil's dwellings. Big John killed the devil, but then dies himself and goes to hell. The devil's wife refuses Big John and slams the door. He then goes to Heaven, where he also is rejected and forced back to Earth. This is a similar telling to Hurston's in Their Eyes Were Watching God.

The alliteration of the "t" and "th" and assonance of the "uh" sound are present in this quote, “'Two things everybody's got tuh do fuh theyselves. They got tuh go tuh God, and they got tuh find out about livin' fuh theyselves'” (192). Repetition and rhythm are found in the language, "Commenced to sing, commenced to sob and sigh, singing and sobbing.” (192-193). The alliteration here rallies Janie to come full-circle from our early introduction and her intimate first experience of womanhood under the pear tree. She realizes in her young life she is, "like a great tree leaf with things suffered, things enjoyed, and things done and undone. Dawn and doom was in the branches,” her destiny (8). The sequential narration of this text leads to its cyclic, lyrical structure.

Every word counts with lyrical language. Hurston was just as much a scientist as a writer, and when writing a chapter book with no pictures, words have much work to do. 
She uses her surroundings, personal experiences, research, fact gathering, and unusual tidbits to make her writing interesting, and this allows the reader to envelop her vision of the world. During her days of becoming a known writer, the Harlem Renaissance specifically, African-American male writers flooded the market. Therefore, for her and others like her, a voice was needed and found in Zora Neale Hurston. Their Eyes Were Watching God takes this point of view to another level of lyrical language. During the scene of the tragic hurricane, her confrontation with her rabid husband will then play out in court proceedings. She is not concerned about pleasing others, but about being genuine to herself and Hurston, to her authorship. The use of a vernacular idiom ties together the characters and creates believability and dedication. Hurston is in the heart of the up and coming women's movement. The movement is affected by the shift of the masculine identity socially, psychologically, and culturally. Life is a choice; Hurston makes this conscious choice to commit a victory by not selling herself short, but rather celebrates the riches and diversities of the black female vernacular. Hurston selected Eatonville as the primary setting for her novel since it provided a "real" backdrop to the racy love story. Being proud of her heritage, Hurston affords the reader a context of a life that appears carefree and easygoing.

\section{Janie's Movement from Object to Subject}

Just as Hurston travels to seek her solace, Janie does, too, traveling from Nanny's house to Logan's farm, then with Jody to Eatonville, FL, and on to the muck in the Everglades with Tea Cake. This physical movement can be mapped and appears to be dance-like. With the flow of this novel, you have Janie's heroine quest for growth, preservation, and redemption. Each location is an experience that affords Janie a 
stepping stone to the next and transcendence beyond the status quo or what society expected of her during the historical time period of the setting.

Janie’s movements represent a dance ritual for her life. The ritual is exhibited when she is hanging on the gate and kissing Johnny Taylor, to running off with Jody Starks, and working on the muck with Tea Cake. These movements mirror Janie's growth with a crescendo. Her relationships with nature during her marital relationships go from blossoms to maturity and finish with harvest. While with Jody, Janie has a period of no growth. This lack of growth then propels her to make her upcoming movement to the next phase of her life. Janie feels chained to Jody through his silencing of her. Her hair tied up represents these chains; however, as it swings free she gains spiritual growth and we see her movement. When Janie is with Tea Cake, she moves freely. She learns new things, like how to play checkers, work on the muck, and shoot a gun to defend herself. When she stands up to Mrs. Turner and Tea Cake near the end, this represents her refusal to dance to someone else's tune.

Janie’s journey, while geographical, is also one of introspection and self-worth. “Ships at a distance have every man's wish on board. For some they come in with the tide. For others they sail forever on the horizon, never out of sight, never landing until the Watcher turns his eyes away in resignation, his dreams mocked to death by Time. That is the life of men" (Hurston 1). The opening of this novel is moving and foreshadowing for Janie's, our protagonist's, encounter with a larger storm to come, both literal and figurative. The "Watcher," our unconscious future, and "Time," capitalized for emphasis, are the inevitable punisher and mentor to Janie. Her true love, partner, and "dream" is Tea Cake, he will be taken or "never landing” to live happily ever after 
together. Janie is "mocked to death by Time" in waiting for a man's love like Tea Cake gives her. Janie will be mocked again in the loss of him during the trial and amongst the townspeople upon her return to Eatonville, FL. Janie compares her life to a "great tree" and "Dawn and doom was in the branches" (8). This is a metaphor Hurston uses to express Janie’s journey ahead. As a prelude to the introduction to Janie, Hurston states “women forget all those things they don’t want to remember, and remember everything they don't want to forget. The dream is the truth" (1). Janie clings to these memories and her dreams of a relationship with compassion, which she sees as the truth.

The "Watcher" is "judgment," which is the last word in both paragraphs three and four from the beginning, chapter one. Upon Janie's return from the horrific hurricane toward the end of the novel, she notices "the sudden dead, their eyes flung wide open in judgment" and she concluded they were forced to encounter and see something they feared and had regret for not heading the warnings. Janie, on her way back to Eatonville from these events, comments on how the townspeople sat on the porch in judgment. The townspeople lack the life experiences that Janie has had to spew such comments from their mouths, but felt they were powerful in their cattiness. They were experts at gossip, "It was a hope that she might fall to their level some day.” Janie paid them no mind. "The people all saw her come because it was sundown. The sun was gone, but he had left his footprints in the sky.” The sundown speaks to Janie's age and experiences, coming full-circle from the start to the end of the novel, life. "Folkses, de sun is goin' down. De Sun-maker brings it up in de mornin', and de Sun-maker sends it tuh bed at night." "All we can do...is tuh make some light ourselves” (45). 
Janie recognizes the benefits of a healthy male relationship early in her life and from her mother's and grandmother's experiences. It is expressed in the dialogue of this talking book; Janie’s need for affection is a requirement for life -

It was a spring afternoon in West Florida. Janie had spent most of the day under a blossoming pear tree in the back-yard. She had been spending every minute that she could steal from her chores under that tree for the last three days. That was to say, ever since the first tiny bloom had opened. It had called her to come and gaze on a mystery. From barren brown stems to glistening leaf-buds; from the leaf-buds to snowy virginity of bloom. It stirred her tremendously. ... Then Janie felt a pain remorseless sweet that left her limp and languid. (10-11)

She is blinded by her "glossy leafs" and the "pollinated air" (11) into kissing the ragged, "trashy” Johnny Taylor. Her grandmother is asleep at the time, dreaming this up to be a nightmare, but it was not. It was reality. Nanny prays “'Lawd, Lawd, Lawd!” and “'half sung, half sobbed..., chantprayer” (14). Nanny knows her days are numbered, “"Ah'm done ole”” and the “'angel wid de sward is goin' tuh stop by here”” (15). Janie’s mom was given better opportunities than Nanny, but was raped by her school teacher. Janie was approaching the age her mom was when this occurred. Her mother afterward took to "drinkin' likker and stayin' out nights" (19). Janie is the product of this rape, the offspring. Grandmother knows her daughter “'ain’t dead, 'cause Ah’d know it by mah feelings, but sometimes Ah wish she was at rest.” This is Nanny's wish to end such sorrow and misery. Nanny does not want the same or something similar to happen to Janie. 
At the moment with Johnny Taylor, Janie’s search for love began and sets the tone for her future dreams, a man she loves who loves her back in marriage. The lyrical language is musical and has a poetic rhythm that is enticing and tantalizing in and of itself. This world of glorious love was sought out, but under the stern protection of her grandmother. She "was in bloom” and was no longer a child. Her "gate” was open. Her grandmother was not going to let Janie be irresponsible with her life, and she married her off to Logan Killicks, “ole skullhead in de grave yard” (13). Janie was not meant to grow to love him. Janie resented her grandmother for not seeking happiness for Janie. Hurston even compares her actions to a Cheshire cat, full of trickery and hidden motives, with no true goal of happiness.

Shortly after the marriage and Nanny’s passing (seasons and pollen), she meets Jody Starks while standing by the gate again. "She knew now that marriage did not make love. Janie’s first dream was dead, so she became a woman” (25). “... He [Jody] did not represent sun-up and pollen and blooming trees, but he spoke for a far horizon,” something more than what she had now (29). Jody is the solution to Logan. Jody does compare Janie to a baby, stating she must still crave "sugar-tits," which was a pacifier during the historical time period of the setting (28). The scene does provide a flash forward to how Jody will treat her, as a child. He should respect her as an adult, but he does not. She tempts Logan by warning him of her running off and, while it makes him ache, he counters, “'Tain’t too many mens would trust yuh, knowin’ yo’ folks lak dey do"” (30). She was hesitant, but did run off with Jody "down” the road. The word “down” is a hint at Jody’s future treatment of Janie personally and socially. When she makes the ultimate decision to leave Logan, she is fit to make it on her own whether Jody 
meets her at their agreed place, the gate, or not. Janie welcomes the change, "The change was bound to do her good,” and upon when she takes leave she compares the air to the empowerment and confidence of a new dress (32). "She was going to have flower dust and springtime sprinkled over everything.” Janie works to make this new bloom "fit."

Jody, Brother Starks - one family in the eyes of God -- is given an enormous reception for the successes of the town as mayor, but when the townspeople give Janie the floor to say a few nice things about her husband, he is fit to keep her "down." “‘Thank yuh fuh yo’ compliments, but mah wife don’t know nothin' 'bout no speechmakin'. Ah never married her for nothin' lak dat. She's uh woman and her place is in de home”" (43). This took the "bloom” off things. Jody is imitating a white patriarchal power structure and the role of women within that framework, which he holds in high esteem.

Jody wants to fix up the town "tereckly" or directly (40). This success for the town, in turn, destroys Janie and Jody's loving relationship. When the town gets its first street lamp, Joe says, “'let de light penetrate inside of yuh, and let it shine, let it shine, let it shine"” (45). Jody's acknowledgment is juxtaposed in relation to Janie as he further confines her. The town then takes up a chant about the light and being amongst it. The town told stories and more stories and "sung songs." Janie is asked by Jody if she is proud of their (his) accomplishments. She states, “‘Ah feels lak Ah’m jus’ markin’ time. Hope it soon gits over’” (46). Janie is part and parcel to Jody's success, but not recognized for her contributions. Her point of view discounted, his was the law and order. "She slept with authority and so she was part of it in the town mind." The 
language Hurston uses here provides for the discord and lack of natural love in their home. He was mayor, manager of the only town store, postmaster, and landlord. Joe Starks "cowed the town" and "something [about him] made men give way before him" (47). He exuded all things material and status-related. Jody is the image of power and this would be Hurston's critique of the capitalist patriarchy.

Jody buys them a new, bigger house, and her, a spittoon. In the Zulu culture, to spit is a sign that evil is cast out. (Berglund). Yes, Janie may have chewed tobacco and needed a spittoon, but this also suggests Biblically that Jody viewed Janie as having to spew what evil may have encompassed her. The contradiction here is the flowery designs on the spittoon. This foreshadows Jody's thoughts of Janie, when she defames him in the store and he becomes ill then, refusing to eat her cooking as if she is evil.

Janie's long hair is a sign of her femininity, "The great rope of black hair swinging to her waist and unraveling in the wind like a plume” (2). Jody is appalled she let her hair down in the store and provided the opportunity for someone to touch it. “'Whut make her keep her head tied up lak some ole'oman round de store? Nobody couldn't git me tuh tie no rag on mah head if Ah had hair lak dat”" (49). "The head-rag irked her endlessly. ... Jody was set on it. Her hair was NOT going to show in the store. ... Joe never told Janie how jealous he was” (55). Jody once had caught Walter "brushing the back of his hand back and forth across the loose end of her braid ever so lightly so as to enjoy the feel of it," although Janie was unaware of this encounter. The scene made Jody feel "like rushing forth with the meat knife and chopping off the offending hand." From then on, he "ordered" her to tie it up while in the store. She was there for his viewing and he did not have to say this verbally. 
The townspeople on the porch figure Jody is worried some other man might touch it and it is considered mysterious. They also are aware of how Jody yells when Janie makes a mistake in the store. It "is sort of ungodly" (50). Jody is continuing his capitalist patriarchy by ordering Janie to tie up her hair. The mystery is in the beauty of Janie when she wears her hair down. Keeping the hair hidden, tied-up, makes it a mystery. Janie also is noted as being oblivious to Jody’s hollering. "Joe’s positions and possessions," no one had the "temerity" to test his confidence. The townspeople had made him what he was.

As Jody tried to have Janie be more indentured to him, she did not and questioned her needs, "Every morning the world flung itself over and exposed the town to the sun" (51). The personification is ripe throughout this novel. With the reflection of her soul, she returned to the notion that Jody was not the man she envisioned, but a stepping stone, experience, knowledge. She felt, "battered against" the rock, Jody (54). Janie states, “'You sho loves to tell me whut to do, but Ah can’t tel you nothin' Ah see!’” Jody responds, “'Dat's 'cause you need tellin' ... 'Somebody got to think for women and chillum and chickens and cows. I god, they sho don't think non theirselves' ... 'They just think they's thinkin'. When Ah see one thing Ah understands ten. You see ten things and don't understand one'” (71). The state of her marriage was on her mind and she fought back at times with her "tongue," but this made Jody want her submission more and, at times, he would slap or hit her when she did not deliver the quality he expected and thought he deserved. Her dreams were on hold. Jody was not the "flesh and blood figure of her dreams. Just something she grabbed up to drape her dreams over” (72). "She was saving up feelings for some man she had never seen.” Janie now knows to 
keep her outside and inside feelings separate. She does speak her mind on the store porch, “'It’s so easy to make yo’ - self out God Almighty when you ain’t got nothin’ tuh strain against but women and chickens"” (75). Jody immediately calls her "moufy" and orders her to get the checkers, again asserting authority and dismissing her speech as a rant.

The emptiness in their relationship was overflowing into a donation of material items Jody would buy for Janie to make "Summertime out of lonesomeness" (77). Now thirty-five, Janie found herself separated from her work and taking orders from Jody in the shop, while another part of her was sitting in the shade of a tree taking in the breeze and enjoying the openness. Her shadow is free and splits from the self. It even became her "fix," or drug of choice, for her to be in nature under the shade of a tree, protection. She was trying to be indifferent, but wanted nature and to be stolid, soaking, "up urine [bad] and perfume [positive] with the same indifference.” Jody invited age to debilitate him and wanted the same for Janie, but she did not share his ailments or encouragement of them. Janie had put Jody in his place when it came to her age. He even compares Janie to being as old as Methusalem, also known as Methuselah, a man who lived to be 969 according to the Hebrew Bible. He was always quick to cut her down and condemn her to feel old until Janie had had enough. She spoke her mind, “'Stop mixin’ up mah doings wid mah looks, Jody”” (79). Jody was already fifty, Janie continues, “'You big bellies round here and put out a lot of brag, but 'tain't nothing' to it but yo' big voice. Humph! Talkin' 'bout me lookin' old! When you pull down you' britches, you look lak de change uh life.'” Jody's illusions and irresistibility were gone and so, too, was his perfected self-image, shattered and confirmed through laughter from the porch. 
He had tried to use positions of power to enhance his maleness, but soon he became ill, he had succumbed to health issues, "“Why must Joe be so mad with her for making him look small when he did it to her all the time?’” (81). Talk and gossip surrounded Janie based on Janie and Jody's candid conversation in the store and now, Jody's illness. People came to feed and care for Jody as their mayor, no interest nor thought for Janie. He excluded her from his care, even when she secretly brings a doctor from Orlando, knowing Jody would refuse. Janie, knowing Jody would perish from kidney failure, soon rushed in to say her peace, even if forbidden from entering. She felt like there was “an oxen’s foot on her tongue” (Hurston 84). Not deterred by Jody, she made her peace, which was an internal step into self-reliance. In his dying hours, she finds strength in his weakness. He does not know Janie, but he does know how to worship himself and get others to do the same, figuratively blinding him to Janie's needs in their twenty years of marriage. Janie said to Jody on his death bed, "“Mah own mind had tuh be squeezed and crowded out tuh make room for yours in me’” (86). She had found herself and through his passing would no longer be waiting and wanting. She faced her image in the mirror and found a mature "handsome" woman. "She tore off the kerchief from her head and let down her plentiful hair. The weight, the length, the glory was there" (87). Janie did what the public thought she should in this time of sorrow and celebration of Jody's life. Even in death, Jody commands a crowd, “The Little Emperor of the cross-roads was leaving Orange County as he had come--with the out-stretched hand of power” (88). This was a moment of, "Finish. Eng. Nevermore. Darkness. Deep hole. Dissolution. Eternity.” She was calm and, following the funeral, she permanently let down her hair. Jody only "looked like love” (90). During this period, Janie longed for 
the horizons. "Before she slept that night she burnt up every one of her head rags and went about the house next morning with her hair in one thick braid swinging well below her waist” (89). Responsibility for her happiness is her own, for once, and she may do as she pleases. She was ready to shine.

With the townspeople discussing her availability and Janie being in a position to choose, she is relishing in her freedom. Even with Joe gone, people still treated Janie like the "Empress of Japan" out of respect and honor. She even expresses her love of the freedom, “'To my thinkin’ mourning oughtn’t tuh last no longer’n grief”” (93).

One day Vergible Woods, Tea Cake, entered the shop and invited Janie to a game of checkers, which she never had played. In the heat of the match, Tea Cake jumped her king, but Janie protested. This defining moment of joy, new opportunities, confirmed the potential of a new beau and new relationship. Tea Cake instills in Janie that night that limitations are self-made. He jokingly role-plays in a flirtatious manner with an imaginary person. He even asks for knuckle pudding, to quell the urge, or as a replacement for a kiss (99).

Tea Cake allows Janie to speak freely and gives her the secure realm in which to have fun. The use of metaphor paints Tea Cake as an alleyway tomcat, whiskers and all. Tea Cake, not Janie, suggests this of himself not to warn her, but allow her the thought and perspective of the talkative townies. He does this, too, when their age difference is brought up again by Tea Cake. Janie is a mature woman who might consider anything has the prospect of being better than Logan Killicks or Jody Clark. Janie recognizes Tea Cake could "be a bee to a blossom a pear tree blossom in the spring." (106). "He was a 
glance from God,” her glance, and with this moment the aroma of the air was filled with herbs and spices.

When Tea Cake does commit, Janie questions his intentions, “God may kill me [Tea Cake], if Ah im lyin'” (Hurston 109). God, nature, holds him accountable for his words and the commitment to Janie. Tea Cake introduces her to many more extracurricular activities such as hunting, fishing, and baseball. These activities represent American pastoral activities. Pheoby comments that these are outside of Janie's class and she is passing for something less than she is. Reaffirming the ways her grandma had in mind for her, she begins to further her path to happiness.

Tea Cake schools her in the trade of shooting. Nature is being overcome by man, but the intention of this training is not to kill game, but to protect herself from a "trashy rascal.” “'Even if you didn’t never find no game, it’s always some trashy rascal dat needs uh good killin','” he says. This foreshadows Tea Cake’s tragic demise. When he teaches her to shoot, she takes down small targets during practice to steady her aim and precision. By this time Janie and Tea Cake were living off the land in the muck, the Everglades. They were in it for the connection to nature, the work, and the money. Vegetables are planted in the muck, seasonally. The majority of the workers on the muck were not bright or wealthy. These people, the fields, and even the pianos, saw three lifetimes in one when it was the planting season.

Janie and Tea Cake were entertained while on the muck. They were not concerned about others and were not even aware of the image they were creating until a lady brought it to their attention. This lady was Mrs. Turner and her prerogative was to “lighten up de race.” Mrs. Turner was a weak person who needed Janie to either foil her 
plan or help her accomplish her goal. Janie is not interested in Mrs. Turner's plans, but does seem to lead her along to learn more of her intent, like dangling the carrot in front of the rabbit. Hurston engaged in similar conversations with the men of the Harlem Renaissance, who played the victim just like Mrs. Turner. Hurston had an upbringing within an all-black township, where they were a self-sustaining community, like Janie’s. "Hurston, herself took great pains to disperse the authorial voice, to highlight diegesis over mimesis” (Kauffman 218). Mrs. Turner, the Richard Wrights of the world, pities Janie for her cultural pride, but all she clung to was not Janie herself, but her white, potential for passing, characteristics (Hurston 145).

Janie's tuneful happiness in loving Tea Cake is constant and without angst, but is a devotion unmatched even to God or financial worth. Symbolically, Janie must take Tea Cake's life out of love for him, her and, in the judgment of "Their Eyes," society. Among the harsh conditions created by the hurricane and subsequent flooding, Tea Cake is bitten by a rabies-infected canine. Without proper resources or access to healthcare, his condition deteriorates. He eventually attacks Janie and, in a moment of irony, she must shoot him to save herself.

Her-story of Their Eyes Were Watching God, "Was a woman on a quest for her own identity and, unlike so many other questing figures in black literature, her journey would take her, not away from, but deeper and deeper into blackness, the descent into the Everglades with its rich black soil, wild cane, and communal life representing immersion into black traditions” (Washington xi). Hurston places herself and Janie in a choral voice. By choosing a collective voice, she is making Janie the teller and Pheoby the bearer of retelling the story. The experiences and relationships lead to growth for Janie 
and are in direct relation to their lives. Jody, Tea Cake, and other male characters are static and unchanging.

Janie in Their Eyes Were Watching God experiences this new release and acceptance among those in the muck, where hierarchies are disregarded and good times take center stage. In addition, Janie intimidates Tea Cake and other men through her appearance, as does Hurston. 


\section{BIBLIOGRAPHY}

Billingslea-Brown, Alma Jean. Crossing Borders through Folklore: African American Women's Fiction and Art. Columbia, Missouri: University of Missouri Press, 1999.

Bloom, Harold. Zora Neale Hurston. Philadelphia: Chelsea House, 2003.

Bolles, A. Lynn. "Seeking the Ancestors." Black Feminist Anthropology: Theory, Politics, Praxis, and Poetics. Ed. Irma McClaurin. New Brunswick: Rutgers University Press, 2001.

Boyd, Valerie. Wrapped in Rainbows: The Life of Zora Neale Hurston. New York: Scribner, 2003.

Cartwright, Keith. Reading Africa Into American Literature: Epics, Fables, and Gothic Tales. Kentucky: University Press of Kentucky, 2015.

Cayer, Jennifer A. “Roll yo' hips - don’t roll yo' eyes: Angularity and Embodied Spectatorship in Zora Neale Hurston's Play, Cold Keener." Theatre Journal. 60 The Johns Hopkins University Press, 2008: 37-69.

Dunham, Katherine. “An Evening with Katherine Dunham.” Florida International University, Kovens Conference Center, North Miami. 24 Feb 2004.

Fanon, Frantz. Black Skin White Masks. Trans. Charles Lam Markmann. London: Pluto Press, 1952.

Guerin, Wilfred L. A Handbook of Critical Approaches to Literature. New York: Oxford UP, 1999.

Hooks, Bell. Ain’t I a Woman? Black Women and Feminism. Boston: South End Press, 1981.

"Dialectically Down with the Critical Program.” Black Popular Culture. (1983): 48-55.

"Zora Neale Hurston: A Subversive Reading.” Moving Beyond Boundaries. 2 (1995): 244-255.

Hurston, Zora Neale. "Dance Songs and Tales from the Bahamas." Journal of American Folk-lore. 43 (1930): 294-312.

. "Big Sixteen." Every Tongue Got to Confess: Negro Folk-Tales from the Gulf States. New York: HarperCollins Publishers Inc., 2001: 91-92. 
. "How It Feels to Be Colored Me." I Love Myself: when I am laughing... and then again when I am looking mean and impressive. New York: The Feminist Press, 1979.

. Tell My Horse. New York: Literary Classics of the United States, Inc., 1995.

. Their Eyes Were Watching God. New York: Perennial Classics, 1937.

Jonas, Gerald. Dancing: The Pleasure, Power, and Art of Movement. New York: Harry N. Abrams, Inc., 1992.

Kauffman, Linda S. Special Delivery: Epistolary Modes in Modern Fiction. Chicago: U of Chicago, 1992.

Kaplan, Carla. Zora Neale Hurston: A Life in Letters. New York: Doubleday, 2002.

Krasner, David. “Migration, Fragmentation, and Identity: Zora Neale Hurston's Color Struck and the Geography of the Harlem Renaissance.” Theatre Journal. 53 The Johns Hopkins University Press, 2001: 533-550.

Kraut, Anthea. "Between Primitivism and Diaspora; The Dance Performances of Josephine Baker, Zora Neale Hurston, and Katherine Dunham.” Theatre Journal. October 2003: 433-450.

- Choreographing the folk: the dance stagings of Zora Neale Hurston. Minneapolis: University of Minnesota Press, 2008.

Sayre, Henry. "Performance.” Critical Terms for Literary Study. Ed. Lentricchia and McLaughlin. Chicago: University of Chicago Press, 1995.

Setterberg, Fred. "Zora Neale Hurston in the Land of 1,000 Dances." The Georgia Review. XLVI, No. 4 (Winter 1992): 627-643.

Shmoop Editorial Team. "Their Eyes Were Watching God Writing Style.” Shmoop.com. Shmoop University, Inc., 11 Nov. 2008. We. 24 May 2015.

“Symbols and Metaphors.” Symbols and Metaphors. N.p., n.d. Web. 06 Dec. 2015.

"Uses of the Erotic: The Erotic as Power." Sister Outsider. Pp 53-59.

Ward, Jerry Washington., and Robert Butler. The Richard Wright Encyclopedia. Westport, CT: Greenwood, 2008. Print. 
Weir-Soley, Donna Aza. Eroticism, Spirituality, and Resistance in Black Women's Writings. Gainesville: University Press of Florida, 2009. Project MUSE. Web. 16 Sep. 2015. <https://muse.jhu.edu/>. 